УДК 351.741:342.7

DOI https://doi.org/10.32849/2663-5313/2021.5.19

\title{
Андрій Танько,
}

канд. юрид. наук,

докторант відділу організації освітньо-наукової підготовки

Харківського начіонального університету внутрішніх справ

\section{ФОРМИ ТА МЕТОДИ ПІДГОТОВКИ ПРАЦВНИКІВ НАЩОНАЛЬНОЇ ПОЛІЦЇ УКРАЇНИ ДО РЕАЛІЗАЦІЇ ДЕРЖАВНОЇ ПРАВООХОРОННОЇ ПОЛІТИКИ}

Автором обгрунтовано необхідність удосконалення й урізноманітнення форм і методів підготовки полічейських до реалізації правоохоронної політики держави, від рівня якої безпосередньо залежить результативність роботи Національної поліиії України як провідного суб'єкта забезпечення прав і свобод людини. Уся сукупність форм і методів підготовки полічейських до професійної діяльності у сфері забезпечення прав і свобод людини розподілена відповідно до виконання низки практичних завдань, у яких відображено реалії роботи органів поліиії та конкретні напрями післядипломної та службової підготовки суб'єктів правоохоронної діяльності.

На основі аналізу правознавчої літератури й вивчення методичного досвіду підготовки прачівників полімії до роботи з громадянами у питаннях забезпечення їхніх прав і свобод визначено етапи організації та проведення такої роботи (адаптаційний, особистісно-розвивальний, професіоналізуючий), що було покладено в основу систематизачії обгрунтованого комплексу форм і методів.

Доведено, що вдосконаленню прочесу організації підготовки поліщейських на адаптаційному етапі сприятиме застосування таких методів і форм, як: анкетування з морально-правових питань, групові та індивідуальні консультації, рефлексивні заняття, просвітницькі заходи з формування позитивної соиіальної та особистісної мотивації до роботи з правового захисту населення тощо. На особистісно-розвивальному етапі як найбільш результативні визначено: ділові ігри, розв'язання проблемних ситуаиій, метод обговорення, індивідуальні програми саморозвитку, тренінгові вправи, індивідуальні та групові заняття, організачія обміну досвідом, тематичні диспути, присвячені питанням захисту прав людини, зустрічі з представниками громади, волонтерами, що прачюють у сфері забезпечення прав людини в Україні, тощо. Обгрунтовано, що на професіоналізуючому етапі підготовки поліщейських доречним є використання тренінгових занять для збагачення підходів до просвітнииької роботи в громаді, заходів заохочення інформаційно-комунікаційної активності полічейських, флешмобів i форум-театрів, що демонструють рівень підготовки поліщейських, розуміння ними потреб громадян та єдність із населенням у питаннях розбудови правового сучасного суспільства, форм активної участі полічейських у волонтерській правоохоронній діяльності, масових просвітницьких заходах із поширення правових знань серед населення.

Ключові слова: форми, методи, прачівники, полічія, держава, політика, співпраия, громадяни.

Постановка проблеми. Сьогодні питання ефективної та компетентної роботи працівників Національної поліції у сфері забезпечення прав і свобод людини стає надзвичайно актуальним в аспекті зміни пріоритетів правоохоронної діяльності в Україні, посилення уваги до правового забезпечення населення, реформування принципів і механізмів адміністративно-правового регулювання діяльності органів поліції, утілення в життя моделі сервісної поліції як основи забезпечення законності і правопорядку в роботі всіх підрозділів поліції з громадянами.

Наголосимо, що на етапі докорінного реформування правоохоронної системи
України, перетворення поліції на сервісну службу, яка спрямована на задоволення потреб усіх верств населення у правовому захисті, особливо актуальною стає підготовка працівників поліції до здійснення широкого спектру нових правозахисних завдань, у визначенні яких загальна спрямованість роботи поліції на охорону прав і свобод людини, а також інтересів суспільства і держави займає одне із чільних місць. Нові правоохоронні завдання поліцейської діяльності сьогодні часто виявляються для вітчизняних фахівців інноваційними і вимагають спеціальної підготовки, яка не вкладається у контекст традиційних форм 
і методів професійної підготовки правоохоронців. Серед таких завдань: робота в межах моделі партнерської поліцейської діяльності (Community Policing), налагодження плідної систематичної взаємодії з органами місцевого самоврядування та громадою в напрямі розширення спектру надання правових послуг населенню, організація медійної активності органів поліції, заохочення громадян до партнерської участі у правозахисній діяльності тощо.

Звернемо увагу, що підготовка до вирішення нових завдань, безпосередньо пов'язаних із забезпеченням прав і свобод людини, потрібна і майбутнім фахівцям, і працівникам поліції, які нещодавно стали до роботи, і досвідченим правоохоронцям, яким доводиться засвоювати нові підходи, опановувати нові практики взаємодії з людиною i громадою. Отже, така підготовка не може обмежуватися лише одним видом підготовки, а має бути наскрізною, комплексною, проникати в усі складники професійної підготовки поліцейських (первинну професійну підготовку; підготовку в закладах вищої освіти зі специфічними умовами навчання; післядипломну освіту, службову підготовку) [7], здійснюватися за допомогою різноманітних і разом із цим універсальних форм та методів. Така підготовка має ефективно забезпечувати вирішення завдань, пов'язаних з особистісним і професійним зростанням фахівців, сприяючи розвитку моральних професійно спрямованих якостей та характеристик особистості, становленню високої правосвідомості правоохоронців на основі глибокого розуміння основ законності та правопорядку.

Як наголошуе сучасний вітчизняний учений Д. Швець, для того щоб правоохоронець відповідав новим вимогам часу та міг успішно виконувати свої службові обов'язки в новоствореній поліції, має бути оновлена система конкурсного відбору і професійної підготовки поліцейських з урахуванням досвіду провідних країн Свропи [1, с. 103]. Необхідно додати, що сьогодні йдеться не лише про концептуальне чи змістове перетворення системи підготовки працівників поліції, а й про кардинально новий підхід до розгляду форм і методів професійної підготовки поліцейських, які у зв'язку з упровадженням в Україні європейської концепції навчання протягом життя мають набувати наскрізний, універсальний характер, забезпечуючи ефективний вплив на рівень підготовки фахівців різного віку та рівня кваліфікації, стаючи частиною адміністративного-правового регулювання правоохоронної діяльності, механізмом дієвого впливу на компетентність органів поліції у цілому.
Необхідність посилення змістового та методичного аспекту підготовки поліцейських відображена в Законі України «Про Національну поліцію», наказах МВС України «Про затвердження Положення про організацію службової підготовки працівників Національної поліції України» (2016р.) $\mathrm{i}$ «Про затвердження Змін до Положення про організацію службової підготовки працівників Національної поліції України» (2020р.), а також інших нормативних актах, де підкреслюється, що поліцейські мають постійно вдосконалювати рівень своєї професійної підготовки до втілення основної мети роботи органів поліції - забезпечення прав і свобод людини, захисту інтересів суспільства і держави, протидії злочинності та підтримки національної безпеки України. Відповідно, гостро постає проблема дослідження, упорядкування, розроблення форм і методів підготовки працівників поліції як суб'єктів втілення державної політики із забезпечення прав і свобод людини в Україні, вирішення якої здатне позитивно вплинути на ефективність роботи Національної поліції в напрямі правозахисної роботи 3 населенням.

Наголосимо, що основою методичного оновлення підготовки працівників поліції до роботи з громадянами в питаннях забезпечення їхніх прав і свобод має стати обгрунтування форм і методів роботи з працівниками поліції, які б забезпечили створення гнучкої системи навчання, у якій враховано реальні вимоги професійного мікросередовища, здійснюється швидке перетворення набутих знань у конкретні вчинки, засвоєння стратегій самовиховання щодо плекання особистісних чеснот (совісті, честі, обов'язку, відповідальності, гідності тощо) і моральних якостей (чесності, доброти, дисциплінованості, принциповості, сміливості, надійності, сумлінності тощо). Відповідно, форми і методи підготовки працівників поліції мають бути зорієнтовані на ефективне сприяння підвищенню рівня моральної і правової зрілості особистості поліцейського, що забезпечує свідоме виконання фахівцем загальносуспільних та професійних обов'язків у сфері забезпечення прав і свобод людини.

Зазначене зумовило посилення науковопрактичної уваги до вдосконалення процесу підготовки поліцейських до роботи із забезпечення прав і свобод людини в Україні. У наукових і науково-практичних розробках вітчизняних учених (І. Антонова, О. Балинська, О. Бандурка, Р. Благута, А. Герасимова, Л. Гуменюк, А. Деркач, О. Дрозд, О. Свдокімова, А. Журавльов, Ю. Забродін, З. Кісіль, О. Ковбич, А. Комзюк, М. Корнієнко, В. Ліпницький, О. Музичук, В. Середа, В. Столін, 
С. Шатрава, Д. Швець та ін.) закладено теоретико-методичне підгрунтя для оновлення форм і методів підготовки працівників поліції до правоохоронної діяльності. Дослідники розглядають різні види професійної підготовки курсантів і студентів ЗВО зі специфічними умовами навчання, слухачів системи післядипломної і службової підготовки: фізичної підготовки та фізичного виховання (С. Бортник, К. Бутенко, Р. Голод, Г. Горпинич, М. Калюжний, І. Ковальов, В. Ліпатов, В. Мандрика, Р. Павлов, М. Червоношапка та ін.); тактико-спеціальної, вогневої підготовки (В. Білик, О.Бойко, О. Кузенков, О. Лопаєва, I. Луценко, О. Прокопенко, О. Соколов та ін.), а також психологічної підготовки поліцейських (Т. Вайда, С. Гіренко, М. Іншеков, О. Карпенко, В. Кущенко, О. Литвинов, І. Остапович, В. Поливанюк, В. Пономарьова, В. Степаненко, В Филипська та ін.).

Зміст, форми і методи професійної підготовки працівників поліції висвітлено в роботах В. Бондаренка; засоби та методи розвитку координаційних здібностей майбутніх правоохоронців вивчено А. Заборою, М. Ісаєвою, В. Колєсніковим, Г. Коником; сучасні аспекти організації дистанційної форми навчання в системі МВС України розглянуто Н. Боборо, К. Бугайчуком, А. Лазутським, I. Марценюком, В. Пилипенко, М. Фіалкою. Можливості використання поліцейського квесту в процесі підготовки фахівців обгрунтовано Ю. Христовою; доцільність застосування інтерактивних методів навчання у процесі професійної підготовки майбутніх працівників системи МВС визначено Т. Івашковим та ін.

Разом із цим питання розроблення форм і методів наскрізної підготовки працівників Національної поліції України до реалізації державної правоохоронної політики залишаються в колі актуальних і малодосліджених.

Метою статті є обгрунтування комплексу форм і методів підготовки поліцейських до правоохоронної діяльності 3 населенням як чинника забезпечення результативності роботи Національної поліції України у сфері реалізації державної політики із ॥ забезпечення прав і свобод людини.

Завдання дослідження:

- на основі аналізу законодавчої та теоретично-методичної бази підготовки працівників поліції впорядкувати форми і методи підготовки поліцейських відповідно до реальних правозахисних завдань, які виконують ці працівники, та конкретних умов і процедур професійної підготовки суб'єктів правоохоронної діяльності;
- обгрунтувати комплекс форм і методів підготовки працівників поліції відповідно до різних етапів організації наскрізної, комплексної підготовки поліцейських до роботи у сфері реалізації державної політики із забезпечення прав і свобод людини.

Наукова новизна дослідження полягає в обгрунтуванні комплексу методів і форм підготовки працівників поліції, що актуалізуються в контексті необхідності здобуття співробітниками органів Національної поліції нових знань, умінь та навичок у сфері захисту прав і свобод людини в умовах сучасних правових викликів та соціальних трансформацій, зростання ролі постійного особистісно-професійного розвитку фахівця протягом життя. Авторський внесок також полягає у висвітленні універсальних форм і методів підготовки поліцейських до роботи із забезпечення прав і свобод населення України, застосування яких $є$ можливим у різних видах професійної підготовки поліцейських (первинна, післядипломна, службова), а також упорядкуванні усього комплексу форм і методів відповідно до етапів професійного становлення фахівців (адаптаційного, особистісно-розвивального, професіоналізуючого).

Виклад основного матеріалу. Докорінне перетворення правоохоронної системи України спричинило зміну вимог до характеру, якості та рівня професійної підготовленості поліцейських до вирішення питань захисту прав і свобод кожного члена українського суспільства, зумовило особливу увагу законодавців та вчених до питань адміністративноправового забезпечення підготовки правоохоронців, оновлення форм і методів організації освітньої і виховної роботи з ними.

Узагальнюючий аналіз наукових робіт дослідників-правознавців (О. Балинська, О. Бандурка, Р. Благута, О. Безпалова, В. Венедиктов, Л. Гуменюк, І. Зозуля, В. Кім, 3. Кісіль, М. Коваль, 3. Ковальчук, О. Ковбич, Д. Кравцов, В. Лапшина, А. Маркова, В. Медведєв, О. Музичук, I. Нестерова, Я. Посохова, I. Семенюта, В. Середа, О. Скакун, С. Сливка, О. Тімченко та ін.) показує, що сьогодні як ніколи актуальності набуває вдосконалення в різних інституціях (закладах вищої освіти зі специфічними умовами навчання, закладах післядипломної освіти, на робочому місці в ході службової підготовки) форм і методів підготовки працівників поліції до роботи в правоохоронних органах щодо забезпечення прав і свобод людини. Розроблення таких форм і методів має грунтуватися на врахуванні загальних етапів професійного становлення особистості і відповідних освітньо-інформаційних 
потреб суб'єктів правоохоронної діяльності, особливостей діяльності всіх структур підготовки правоохоронців (первинної професійної підготовки; підготовки в закладах вищої освіти зі специфічними умовами навчання; післядипломної освіти, службової підготовки), а також соціально-психологічних характеристик сучасної професійної молоді, слухачів і курсантів системи МВС України, працівників органів Національної поліції, що визначає специфіку індивідуальної траєкторії професіоналізації правоохоронця.

Посилаючись на розробки зазначених вище вчених, наголосимо, що під час обгрунтування форм і методів підготовки працівників Національної поліції України до реалізації державної політики у сфері забезпечення прав і свобод людини необхідно зважати на те, що як первинна підготовка слухачів і курсантів, так і післядипломна та службова підготовка працівників поліції спрямовані сьогодні, насамперед, на прищеплення правоохоронцям загальнолюдських гуманістичних та морально-правових цінностей, оновлення фахових знань щодо норм правового суспільства як методологічної бази для поширення та підтримки у поліцейській діяльності високих професійних стандартів, виключення неправових дій, підтримання норм професійної доброчесності, законності і порядку.

Важливо зазначити, що освітня та просвітницька робота зі співробітниками поліції, слухачами і курсантами, спрямована на підвищення рівня їхньої підготовленості до роботи 3 населенням на високих морально-правових засадах, є природно взаємопов'язаною з існуючою практикою поліщейської діяльності у сфері правового забезпечення громадян, iї суть полягає у задоволенні існуючих потреб жителів України у правовому захисті та охороні. Тому підготовка поліцейських до такої роботи має зосереджуватися на активному особистому залученні фахівця і глибокому його зануренні у процес засвоєння навичок щодо побудови професійної поведінки на непримусових високих етичних стандартах, особистісно значущих загальнолюдських цінностях, що потребує розроблення і використання відповідних форм та методів підготовки. Тоді результат підготовки поліцейських до правоохоронної діяльності 3 громадянами у питаннях забезпечення прав і свобод людини відображатиме на індивідуально-особистісному рівні функціональну сукупність їхніх морально-етичних особистісних характеристик та професійноправових знань та вмінь, сприятиме набуттю фахівцем власної гідності та поваги до гідності інших, спонукатиме до активної життє- вої позиції, забезпечуючи набуття професійної самоідентичності, тощо.

Зазначене вище надає можливість обгрунтовано з погляду науки й доцільно 3 позицій практики розробити комплекс форм і методів підготовки поліцейських до реалізації державної політики у сфері забезпечення прав і свобод людини, верифікувати ïx, здійснивши впровадження в реальний процес підготовки правоохоронців.

Уся сукупність таких форм і методів може бути розподілена відповідно до тих загальних викликів професійного зростання, з якими, як правило, зустрічається працівник поліції як суб’єкт реалізації державної правоохоронної політики, рухаючись власною траєкторією професійного розвитку. Виходячи 3 аналізу практики діяльності працівників поліції в галузі забезпечення прав і свобод людини ми виокремили деякі нагальні завдання і проблеми щодо особистісного і професійного зростання поліцейських як суб'єктів правоохоронної діяльності і взаємодії з громадянами та відповідні форми і методи підготовки, які сприятимуть їх вирішенню:

1. Необхідність постійного вивчення фахівцем особливостей сучасного правового поля та соціального середовища, у якому правоохоронцю належить виконувати професійні обов'язки, ознайомлення з ризиками й упередженнями, що існують у цьому середовищі всупереч прогресивному державному законодавству й зумовлюють поширення дискримінаційних норм, цінностей та ідеалів, що можуть негативно впливати на співробітника, спричиняти проблеми під час його взаємодії з громадянами. Форми і методи підготовки правоохоронців, що забезпечують розв’язання цієї групи завдань, зорієнтовані на забезпечення розвитку особистісної стійкості поліцейських до асоціальних норм, які de facto можуть нав'язувати існуючі суспільні практики чи навіть застарілі традиції правоохоронної діяльності. Це можуть бути різноманітні форми і методи інтерактивного навчання, освітні семінари та вебінари тощо.

2. Подолання наслідків впливу на суб'єкта правоохоронної діяльності умов служби, пов'язаних з емоційним і фізіологічним напруженням, можливими негативними наслідками взаємин із колегами, що допускають зловживання власними повноваженнями, недбале ставлення до виконання професійних обов'язків. Для запобігання подібним впливам та вирішення проблем, пов'язаних із його наслідками, доречними є дискусійні форми, методи роз'яснення професійних ризиків, до яких належать ненормований робочий день, незадоволення своїм матеріальним становищем та пошук шляхів 
уникання наслідків їхнього впливу та професійного вигоряння у цілому.

3. Попередження можливих професійних деформацій, зумовлених низьким рівнем морально-правової готовності поліцейських до дій із захисту прав і свобод людини в умовах надзвичайних ситуацій. Методи і форми, які застосовуються для вирішення такого завдання, передбачають обговорення неприпустимості зловживання власними повноваженнями, бездушного й іноді жорстокого ставлення до затриманого, а іноді й до свідків і потерпілих, нехтування нормами права та службової етики, використання в боротьбі зі злочинністю незаконних методів, ухилення від виконання своїх обов'язків, небажання приймати самостійні рішення.

4. Формування позитивної соціальної та особистісної мотивації щодо служби в органах поліції, заснованої на розумінні великої громадянської ролі поліцейського, прагненні досягти професійного і кар'єрного зростання сумлінним виконанням службового обов'язку зі служіння людям і суспільству. Основу такої роботи мають становити форми і методи, що відображають історичний досвід вітчизняної правоохоронної діяльності, патріотичні приклади з історії діяльності поліції у світі, вивчення досвіду найкращих співробітників сьогоднішньої поліції.

На основі аналізу правничої літератури (Р. Благута, О. Балинська, Л. Гуменюк 3. Ковальчук, О. Ковбич, В. Середа [2], В. Кононець [3], О. Мердова [4], Д. Швець [5] та ін.) та вивчення практики роботи працівників поліції з громадянами у питаннях забезпечення їхніх прав і свобод цілісно розглянуто процес наскрізної підготовки фахівців, що охоплює три етапи: адаптаційний, особистісно-розвивальний, професіоналізуючий. Зважаючи на це, з позиції адміністративно-правового регулювання діяльності органів поліції можемо проаналізувати питання організації та проведення необхідних заходів, відповідно розподіливши весь комплекс форм і методів підготовки поліцейських до правоохоронної діяльності.

Так, адаптаційний етап забезпечує залучення майбутніх правоохоронців до різних форм самовиховання, розвиток у них мотивації до самовдосконалення у питаннях роботи з громадянами щодо забезпечення прав і свобод людини, призвичаювання у колективі, інтеграцію фахівцями професійних цінностей та пріоритетів, моральних правил і норм професійного середовища. Під час його реалізації, окрім організаційних (підготовка всіх суб'єктів освітньої роботи з поліцейським складом до спільного планування та скоор- динованих дій з підвищення рівня правової та особистісної компетентності співробітників у різних формах навчання; підвищення педагогічного рівня керівників підрозділів, які безпосередньо реалізують освітню і просвітницьку роботу), вирішуються виховні завдання: організація роботи 3 поліцейськими щодо самовивчення особистості, отримання досвіду рефлексивної діяльності, усвідомлення та подолання власних проблем, пов'язаних із входженням у професійний колектив; ознайомлення 3 особливостями та вимогами професійної діяльності; розвиток мотивації у напрямі забезпечення прав і свобод людини, служіння суспільству.

Як підкреслює Г. Андросюк, під час адаптації поліцейського відбувається перехід від кількісних (розширення кола знань, оволодіння способами та прийомами нових дій, послідовне формування впевненості у власних силах, внутрішне позитивне ставлення до нових завдань та умов діяльності, поведінки) до якісних змін у структурі особистості правоохоронця, що дають йому змогу успішно опанувати нові види діяльності. Відповідно, сутнісною характеристикою ефективності функціонування механізму професійної адаптації молодого поліцейського, що позначається на виборі форм і методів його підготовки на адаптаційному етапі професійного зростання, можна вважати результативність самоосвіти особистості щодо засвоєння статусно-рольових і нормативних вимог, орієнтацій, умов нового соціального середовища [6, с. 104-105]. Тому, організовуючи роботу 3 вирішення завдань професійної підготовки поліцейських до правоохоронної діяльності, необхідно сформувати у них свідоме ставлення до процесу професійної адаптації, основане на високоетичних професійних мотиваційних установках, формуванні внутрішніх потреб у прояві моральної поведінки, прагненні до професійного зростання, використовуючи для цього такі форми і методи підготовки, як:

- анкетування 3 морально-правових питань із метою виявлення існуючих соціально-педагогічних та психологопедагогічних проблем;

- групові та індивідуальні консультації за участю наставників, співробітників психологічної служби для обговорення конкретних проблемних ситуацій навчання, адаптаційних труднощів, формування позитивних етичних настанов, основаних на розвитку здатності до саморефлексії;

- організація для особового складу зустрічей та консультацій із правових питань iз залученням юристів, представників органів місцевого самоврядування; 
- проведення рефлексивних занять щодо навчання прийомів самовивчення особистості та саморегуляції їі розвитку в напрямі підвищення рівня особистісної і професійної підготовленості майбутнього фахівця (самодисципліни, самоорганізації, психофізичної витримки, моральної стійкості тощо);

- організація просвітницьких заходів із формування позитивної соціальної та особистісної мотивації щодо служби в поліції, заснованої на розумінні великої громадянської ролі роботи правоохоронних органів, прагненні досягти професійного і кар'єрного зростання сумлінним виконанням службового обов'язку;

- застосування ділових ігор, розв’язання проблемних ситуацій, обговорень, спрямованих на ознайомлення з вимогами сучасної роботи поліцейського в Україні й за кордоном;

- тематичні виставки, присвячені урочистим подіям чи конкретним персоналіям, які оприлюднюють та унаочнюють інформацію, що сприяє популяризації серед працівників поліції, слухачів та курсантів ідей сумлінного підходу до роботи на засадах недискримінації, законності, прозорості й відкритості до громади;

- проведення розширених днів кафедр у закладах первинної підготовки поліцейських із запрошенням правоохоронців-практиків, що дає змогу не лише організувати передавання професійного досвіду в неформальних умовах, а й розповісти про майбутню професію, професійну етику та норми професійних ділових відносин;

- зустрічі $з$ досвідченими працівниками, які б ділилися досвідом професійної діяльності, розповідали про роки навчання, цікаві професійні ситуації морального вибору;

- професійні свята (наприклад, День поліції, День рятівника, які вшановують діяльність працівників аварійно-рятувальних служб, пожежної охорони, інших спеціальних формувань, а також громадян, які зробили свій внесок у справу ліквідації наслідків надзвичайних ситуацій техногенного та природного характеру, захисту життя і здоров'я людей);

- вправи та психолого-педагогічні ігри, які стимулювали б мотиви колективізму та взаємодопомоги, боротьби за честь свого колективу;

- мотивуючі заняття із застосуванням бесід, ігор, тренінгів (наприклад, бесіда «Особиста дисципліна поліцейського - шлях до успіху у професії», тренінг самоконтролю, моделююча гра «Допомога правоохоронця» тощо).

Спираючись на власний професійний досвід, зазначимо, що на особистісно-розвивальному етапі відбувається формування у працівників поліції професійно важливих якостей та характеристик, закріплення знань та вмінь, що становлять змістову основу роботи працівників поліції з громадянами в питаннях забезпечення їхніх прав і свобод. Тому в процесі роботи з працівниками поліції має підкреслюватися специфіка морального складника особистості правоохоронця, який полягає у глибокій повазі до закону, вірності правовим нормам, моральній стійкості й несхильності сторонньому впливу, самостійності в судженнях, пильності, вимогливості до себе і до людей, чесності і непідкупності, скромності, ввічливості, мужності та рішучості, емоційній стійкості, витримці, такті, зібраності, внутрішньому спокої. Ознайомлення зі специфікою професійної діяльності працівників поліції переконливо свідчить, що моральні якості та характеристики безпосередньо виявляються та формуються у період неформального спілкування, становлення взаємин, вирішення побутових питань. Тож у підготовці правоохоронців необхідно приділяти особливу увагу формуванню їхніх особистісних якостей та попередженню можливих професійних деформацій, зумовлених низьким рівнем морально-правової культури у різних формах підготовки, через реалізацію таких заходів:

- тренінгові вправи на підвищення рівня сформованості у поліцейських основ дисципліни та самодисципліни, навичок самоконтролю як запоруки протистояння професійним викликам;

- диспути «Що означає сумлінно виконувати свій обов'язок?», «Яким повинен бути справжній поліцейський?», «Що означає віддано служити Батьківщині?», «Чи завжди в житті є місце подвигу?»;

- збори для обговорення проблемних ситуацій, що складаються у роботі працівників поліції, з подальшим розглядом підсумків на службовій нараді начальницького складу;

- консультації з працівниками психологічної служби, озброєння співробітників поліції індивідуальними програмами саморозвитку в напрямі підготовки до роботи із забезпечення прав і свобод людини, знаннями та вміннями щодо саморозвитку і самовиховання з урахуванням індивідуальних особливостей та потреби у підвищенні рівня культури спілкування з громадянами;

- заняття 3 гуманітарної підготовки за темами: «Правова основа життя», «Життя та здоров'я людей - головна цінність держави», «Наркоманія, алкоголізм, ВІЛ/СНІД як соціальні проблеми: стан, тенденції, шляхи попередження», «Насилля і дискримінація - сучасні виклики правоохоронної діяльності» тощо; 
- майстер-класи і вебінари з підвищення рівня комунікативно-інформаційної культури поліцейських, що дає змогу посилити співпрацю служби поліції з населенням у питаннях забезпечення прав і свобод людини, заохочення працівників поліції до використання можливостей IT-технологій для оновлення форм просвітницької діяльності з громадянами (ведення власного правового блогу, створення груп і ведення просвітницьких сторінок у соціальних мережах тощо);

- нові форми масової роботи з населенням (форум-театри, флешмоби, поліцейські квести тощо), що передбачають участь працівників поліції з метою популяризації правових знань, формування позитивного іміджу служби поліції серед населення;

- зустрічі з представниками громади, волонтерами, що працюють у сфері забезпечення прав людини в Україні.

На третьому, професіоналізуючому, етапі підготовки працівників поліції до правоохоронної професійної діяльності освітній вплив має бути зосереджений на відпрацюванні ними правоохоронних знань та вмінь, формуванні загальної культури правоохоронців, пов'язаної з розумінням ієрархії правових та моральних цінностей у житті людини, зокрема й у професійній сфері, засвоєнням активної громадської позиції, формуванням суб'єктності фахівця на основі визначення стратегії поведінки та професійної діяльності поліцейського з урахуванням громадянських, моральних, правових норм.

Очевидно, що вирішення цих завдань пов'язано 3 розширенням світогляду працівників поліції; оновленням навичок професійної комунікативної культури; профілактикою професійного вигоряння, сприянням збереженню фізичного, психічного та морального здоров'я, задоволенням морально-естетичних та культурних потреб особистості; посиленням здатності протидіяти правопорушенням, проявам бездуховності, антигромадської діяльності; підвищенням рівня психологічної та фізичної готовності фахівців до виконання громадянського та конституційного обов'язку щодо відстоювання національних інтересів і незалежності держави, підвищення престижу державної служби; створенням умов для подальшого розвитку громадянської активності, професіоналізму, високої мотивації до праці як основи конкурентоспроможності громадянина, а отже, держави.

Для цього доцільними $є$ такі форми і методи:

- індивідуальні та групові заняття, присвячені питанням розвитку та саморозвитку правоохоронцями психолого-педагогічних ресурсів власної особистості, власних психофізичних особистісних якостей;

- додаткові заняття 3 тактико-спеціальної, вогневої, фізично-спортивної підготовки, спрямовані на посилення вольової сфери правоохоронця, підтримку його бойової готовності;

- організація роботи груп активного соціального навчання, відеотренінгу, вправ із невербального спілкування для набуття працівниками поліції навичок самоаналізу, емоційної і поведінкової саморегуляції в найскладніших умовах майбутньої професійної діяльності;

- професійно-психологічний тренінг реалізації владних повноважень для профілактики і корекції таких видів відхилень від правомірної реалізації повноважень, як перевищення посадових повноважень і незастосування владних повноважень у тих ситуаціях, у яких це передбачено законодавчо;

- організація самопідготовки перемінного складу щодо підвищення професійного рівня, активізації самостійної роботи стосовно постійного оновлення знань щодо правових основ роботи поліції;

- обмін досвідом із зарубіжними колегами, участь у міжнародних нарадах, конференціях, семінарах, програмах зарубіжного стажування тощо;

- масові просвітницькі заходи з поширення правових знань серед населення (акції серед учителів, учнів шкіл, їхніх батьків: «Мої права, мої обов'язки», «Обличчя правоохоронця», «Кримінальна відповідальність у дитячому віці»; флеш-мобах «Я - правоохонець», «Вони воювали за Батьківщину»);

- форми активної участі поліцейських у волонтерській правоохоронній діяльності: робота в безкоштовних консультативних пунктах для громадян; телефонах довіри; широка участь у заходах із попередження насильства в сім'ї, зокрема насильства над дітьми, тощо

\section{Висновки}

У цілому, підсумовуючи результати вивчення досліджуваної проблеми, зазначимо, що з позиції адміністративно-правового регулювання діяльності органів поліції вся сукупність форм і методів підготовки працівників Національної поліції України як провідних суб'єктів реалізації державної політики із забезпечення прав і свобод людини може бути розподілена відповідно до реальних проблем поліцейської діяльності:

- форми і методи виховної роботи з правоохоронцями зорієнтовані на забезпечення розвитку особистісної стійкості поліцейських до асоціальних норм, які можуть 
нав’язувати існуючі суспільні та професійні практики;

- дискусійні форми і методи для роз'яснення професійних ризиків та пошуку шляхів уникання наслідків їхнього впливу та професійного вигоряння у цілому;

- профілактичні методи і форми, які передбачають обговорення неприпустимості зловживання власними повноваженнями, бездушного ставлення до людини, зокрема до затриманого, свідків і потерпілих, нехтування нормами права та службової етики, використання в боротьбі зі злочинністю незаконних методів;

- форми і методи, що забезпечують підвищення рівня громадянської культури поліцейських, ознайомлення правоохоронців із патріотичними прикладами з історії правоохоронної діяльності в Україні та світі, вивчення досвіду найкращих співробітників сьогоднішньої поліції тощо.

На основі аналізу юридичної літератури та вивчення практики роботи працівників поліції з громадянами в питаннях забезпечення їхніх прав і свобод цілісно розглянуто процес їх наскрізної підготовки, що охоплюе три етапи: адаптаційний, особистісно-розвивальний, професіоналізуючий, відповідно, розподілено весь комплекс форм і методів підготовки поліцейських до правоохоронної діяльності: на адаптаційному (анкетування, групові та індивідуальні консультації, рефлексивні заняття, просвітницькі заходи тощо), особистісно-розвивальному (ділові ігри, обговорення, індивідуальні та групові заняття, зустрічі з представниками громади, години культурно-освітньої роботи, метод проблемних ситуацій), професіоналізуючому (індивідуальні програми саморозвитку, тренінгові вправи, зустрічі з обміну досвідом, тематичні диспути, заняття з тактико-спеціальної, вогневої підготовки, фізично-спор- тивної підготовки, форми активної участі у волонтерській діяльності, масові просвітницькі заходи з поширення правових знань серед населення тощо).

Перспективним напрямом подальших досліджень порушеної проблеми є методичне розроблення та впровадження конкретних заходів із підвищення рівня підготовки працівників поліції у сфері забезпечення прав і свобод людини на різних етапах професійного становлення.

\section{Список використаних джерел:}

1. Швець Д.В. Первинна професійна підготовка як необхідна правова вимога до підготовки поліцейських. Право $і$ безпека. 2017. № 3. C. $103-112$.

2. Теоретико-прикладні засади конструктивної взаємодії поліції і населення в соціумі : монографія / В.В. Середа та ін. ; за заг. ред. З.Р. Кісіль. Львів : ЛьвДУВС, 2017. 600 с.

3. Кононець В. Взаємодія підрозділів Національної поліції з громадськістю. Профілактика правопорушень : конспект лекцій. Дніпро : Дніпропетровський державний університет внутрішніх справ, 2016. 68 с.

4. Мердова О.М. До питання про професійні компетентності поліцейського. Юридична наука: сучасний стан та перспективи розвитку : матеріали міжвузівської науково-практичної конференції, м. Київ, 30 листопада 2017 р. Київ : Національна академія внутрішніх справ, 2017. С. 109-110.

5. Швець Д.В. Навчання в процесі практичної діяльності (службова підготовка поліцейського) як втілення еволюційного характеру формування особистості поліцейського в Україні. Право $і$ безпека. 2017. № 4(67). С. 149-159.

6. Андросюк В.Г. Феномен адаптації в контексті діяльності нової поліції України. Юридична психологія. 2017. № 2. С. 100-109.

7. Про Національну поліцію : Закон України від 02.07.2015 № 580-VIII. Відомості Верховної Ради України. 2015. № 40-41. Ст. 1970.

Andrii Tanko. Forms and methods of the National Police of Ukraine officers' training for implementation of the state law enforcement policy

The author substantiates the need to improve and diversify the forms and methods of training police officers to implement the law enforcement policy of the state, the level of which directly affects the effectiveness of the National Police of Ukraine as a leading entity for human rights and freedoms. The whole set of forms and methods of training police officers for professional activities in the field of human rights and freedoms is distributed in accordance with a number of practical tasks, which reflect the realities of police work and specific areas of postgraduate and professional training of law enforcement entities.

Based on the analysis of legal literature and the study of methodological experience of training police officers to work with citizens in ensuring their rights and freedoms, the stages of organization and conduct of such work (adaptive, personal development, professional), which was the basis for systematization of a reasonable set of forms and methods.

It is proved that the improvement of the process of organizing police training at the adaptation stage will contribute to the use of such methods and forms as: questionnaires on moral and legal issues, group and individual consultations, reflective classes, educational activities to form positive social and personal motivation to work on legal protection. etc. At the personal and developmental stage, the most effective are: 
business games, problem solving, discussion method, individual self-development programs, training exercises, individual and group classes, organization of experience exchange, thematic debates on human rights issues, meetings with representatives communities, volunteers working in the field of human rights in Ukraine, etc. It is substantiated that at the professional stage of police training it is appropriate to use training sessions to enrich approaches to educational work in the community, measures to encourage information and communication activities of police officers, flash mobs and forum theaters that demonstrate the level of police training in matters of building a legal modern society, forms of active participation of police officers in volunteer law enforcement, mass educational activities to disseminate legal knowledge among the population.

Key words: forms, methods, workers, police, state, politics, cooperation, citizens. 